\title{
Conceptualizing Indonesia's ICT-based Energy Security Tracking System with Detailed Indicators from Smart City Extension
}

\author{
Erkata Yandri $^{1,2, *}$, Roy Hendroko Setyobudi1 ${ }^{1,3}$, Herry Susanto ${ }^{1}$, Kamaruddin Abdullah $^{1,2}$, \\ Yogo Adhi Nugroho ${ }^{4,5}$, Satriyo Krido Wahono ${ }^{6}$, Feri Wijayanto ${ }^{7}$, and Yanuar Nurdiansyah $^{8}$ \\ ${ }^{1}$ Graduate School of Renewable Energy, Darma Persada University, Jl. Radin Inten 2, \\ Pondok Kelapa, East Jakarta 13450, Indonesia \\ ${ }^{2}$ Center of Renewable Energy Studies, Darma Persada University, Jl. Radin Inten 2, \\ Pondok Kelapa, East Jakarta 13450 \\ ${ }^{3}$ Department of Agriculture Science, Postgraduate Program, University of Muhammadiyah Malang, \\ Jl. Raya Tlogomas No. 246, Malang, 65145, Indonesia \\ ${ }^{4}$ Individual Researcher, Alumni Graduate School of IPB University, Bogor, Indonesia \\ ${ }^{5}$ Data Processing, Rumah Paper - Editage Services, Jl. Tokala No.1, Malang 65146, \\ East Java, Indonesia \\ ${ }^{6}$ Research Division for Natural Product Technology - Indonesian Institute of Sciences, \\ Jl. Jogja - Wonosari, km 31.5, Gunung Kidul, Special Region Yogyakarta 55861, Indonesia \\ ${ }^{7}$ Institute for Computing and Information Science, Radbound University Comenisulaan 4, \\ 6525 HP Nijmegen, The Netherlands \\ ${ }^{8}$ Program Study of Information Technology, University of Jember, Jl. Kalimantan 37, \\ Jember 68121, Indonesia
}

\begin{abstract}
The purpose of this study is to conceptualize Indonesia's ICTbased energy security tracking system with detailed indicators of renewable energy (RE) and energy efficiency (EE) from the smart city extension. The opportunities for improvement to the energy security system is still wide open with the support of advances in information and communication technology (ICT) to integrate the internet and smart grid. The method refers to five main dimensions: availability, efficiency, affordability, sustainability, and governance. Then, how to link the concept of energy security with detailing indicator of RE and EE to the smart city. Empirically, energy security is a function of availability, efficiency, affordability, sustainability, and governance. The most important dimension is the Government (Go) to realize the interconnectivity and the information. If the Go has been realized, the other four dimensions will be easily obtained. With the development of ICT, the energy security status will certainly be more easily accessed anytime and anywhere by the stakeholders. The concept of a smart city usually integrated with the ICT infrastructure, especially for monitoring, management and decision-making tool. This research provides an overview of how the concept of energy security system is closely related to the implementation of the smart grid.
\end{abstract}

Keywords: Energy efficiency, information technology, local government, renewable energy, smart grid

\footnotetext{
*Corresponding author: erkata@gmail.com, erkata@pasca.unsada.ac.id
} 


\section{Introduction}

Energy is one of the important needs of a country in driving its economy; its availability must be guaranteed by the government. If the supply of energy is disrupted, the economy and development of a country are directly affected. To ensure the sustainability of their country's activities, each country has a specific energy strategy to secure its national development. Indonesia's energy strategy has been outlined in Law No. 30 of 2007 on Energy. The energy management strategy is principally based on the principles of benefit, nationality, equal efficiency, economic added value, sustainability, community welfare, environmental sustainability, national security, and integrity. For energy sustainability, three important things must be considered; energy security (ES), energy equity, and environmental sustainability. ES is the effective management of domestic primary energy supply and external resources, the reliability of energy infrastructure, and the ability to provide energy for current and future needs [1]. Energy equity is the ability to provide affordable energy access to all residents of the country. Environmental sustainability is the ability to provide and use energy efficiently, develop renewable energy sources, and other low-carbon energy. The ability of a country to balance these three dimensions is the key to global prosperity and competitiveness. These principles lead to the sustainability of national development and energy security.

The opportunities for improvement to the energy security system is still wide open, especially with the support of advances in information and communication technology (ICT), such as the integration of the internet [2] and smart grid [3], which has a highly disruptive effect on innovation and productivity [4]. The smart grid is a visual infrastructure of the stakeholders to manage the diverse power systems with dynamic interactive real-time [5]. The reliability of national energy security is built on the strength of local energy security. Fortunately, some local governments already have a smart city vision, even focusing on pursuing their vision with the aim of interconnectivity and information between local governments and their city stakeholders. The smart city is the terminology of smart interchangeably and information for smart communities, powered by a smart grid [6]. Moreover, this will also be supported by the planned implementation of the smart grid which is still in the preparation stage. The main driver for the birth of smart city development is technology. Especially ICT, that permits to wire and link different actors in the urban arena and to supply digital services, by both private and public institutions. However, also engineering and other technologies are important, especially aiming to improve logistic, mobility, and environmental sustainability in the city. Figure 1 shows the simple energy security monitoring system concept with interactive-interesting dashboards and easily accessible to stakeholders from anywhere, to facilitate analysis and corrective actions that must be taken immediately.

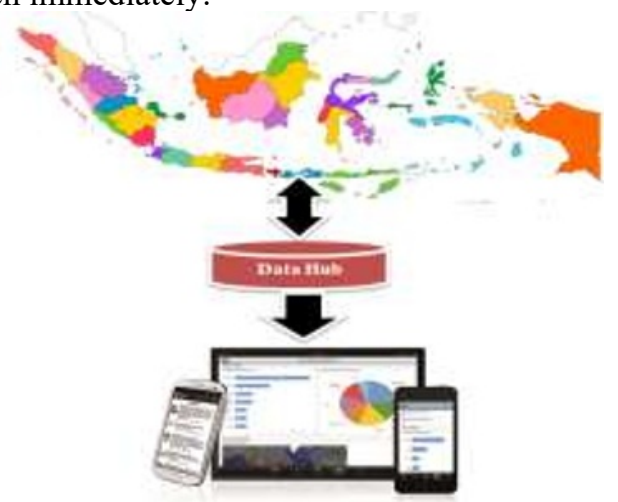

Fig. 1. Energy security dashboard monitoring system concept [7] 
That is the motivation to innovate the energy security tracking and monitoring system with the dashboard by detailing the indicators of renewable energy (RE) and energy efficiency (EE) [8]. The status of ES can be monitored faster and detail in real-time. Energy security stakeholders can take quick and appropriate actions. Based on the above consideration, the objective of this paper is to conceptualize an ICT-based energy security tracking system with detailed indicators into the concept of smart grids technology.

\section{Method}

To understand the concept of energy security with a detailing indicator, several concerns must be discussed. First, referring to the concept and energy security measurement with a synthesis approach [9], ES can be explained in Table 1 below:

Table 1. Energy security dimensions and components [9]

\begin{tabular}{lcl}
\hline Dimension & Components \\
\hline Availability & Af & $\begin{array}{l}\text { Security of supply and production, dependency, } \\
\text { diversification } \\
\text { Price stability, access, and equity, decentralization, } \\
\text { affordability, }\end{array}$ \\
Affordability & Ef & $\begin{array}{l}\text { Innovation and research, safety and reliability, resilience, } \\
\text { efficiency, and energy intensity, investment and employment }\end{array}$ \\
$\begin{array}{l}\text { Technology development and } \\
\text { Environmental and social } \\
\text { sustainability }\end{array}$ Su & Land use, water, climate change, pollution \\
Regulation and governance & $G o$ & $\begin{array}{l}\text { Governance, local and regional interconnectivity, } \\
\text { competition and markets, knowledge and access to } \\
\text { information }\end{array}$ \\
\hline
\end{tabular}

Then, as formulated in $[7,10]$, energy security can be expressed as;

$$
E S=f(A v+E f+A f+S u+G o)
$$

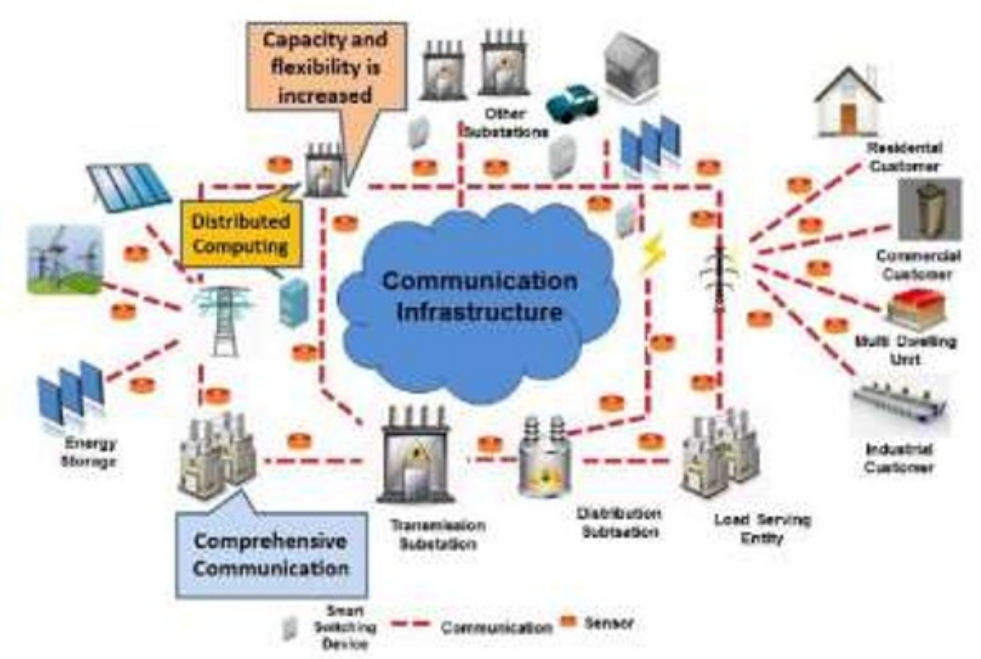

Fig. 2. Smart grid architecture [12]

Second, linking the concept of Energy Security with detailing indicator of RE and EE to the Smart City. The concept of a smart city usually integrated with the use of ICT infrastructure, especially for monitoring, management, and decision-making tool [11]. In the real situation, the system consists of network sensors, servers and internet networks, as 
shown in Figure 2. Network sensors are a collection of sensors placed in a specific place for specific purposes. The sensors have the main function for data collecting from the data sources. The data from the sensor is sent to the server via the Remote Terminal Unit (RTU). The server can be equipped with a database or GIS (Geographical Information System) features. The connection between a network sensor and server use the internet or Transmission Internet Protocol/Internet Protocol (TCP/IP) network. On the server-side, it can use cloud computing infrastructure [12].

\section{Result and discussion}

The concept of detailing energy security measurements is shown in Table 2. Considering data availability and simplifying calculations, not all indicators as suggested in Table 1 are used. Referring to [9], the RE indicator is inclusively in the dimension of availability, while the EE in the dimension of technology development and efficiency, where, $A v, E f, A f, S u$, and $G o$ are the main indicators of Availability, Efficiency, Affordability, Sustainability, and Governance, respectively.

Table 2. Energy security dimensions and components [9]

\begin{tabular}{|c|c|c|c|}
\hline Dimension & \multicolumn{2}{|c|}{ Component and description } & Equation \\
\hline Availability & $A v=f(F E+R E)$ & $\begin{array}{l}\text { The current role of } F E 76.8 \%[13] \text { should } \\
\text { be reduced with more results of RE and EE. }\end{array}$ & (2) \\
\hline & $R E_{\text {ind }}=f(S+N S)$ & $\begin{array}{l}S \text { and NS are Solar and Non-solar, } \\
\text { respectively. At this stage, S and NS only to } \\
\text { simplify it, without neglecting the role of } \\
\text { other renewable energy sources, which can } \\
\text { still be developed in more detail at the next } \\
\text { research stage. }\end{array}$ & $(2.1)$ \\
\hline Affordability & $A f=f(\operatorname{Pr}+A c)$ & $\begin{array}{l}P r \text { and } A c \text { are price stability and } \\
\text { accessibility equity, respectively. Both } P r \\
\text { and } A c \text { refer to the prices and accessibility } \\
\text { of electricity, oil, coal and gas for all } \\
\text { sectors. }\end{array}$ & (3) \\
\hline $\begin{array}{l}\text { Technology } \\
\text { development } \\
\text { and efficiency }\end{array}$ & $E f_{\text {ind }}=f(\mathrm{P}+U+O)$ & $\begin{array}{l}E f \text { can be done in all sectors, such as } \\
\text { industry, commercial, residential, and } \\
\text { transportation. Where, } P, U, O \text { are; process, } \\
\text { utility, and office, respectively. Since } \\
\text { process and utility are the largest energy } \\
\text { users in the industry, the focus should be } \\
\text { more given, regardless of the energy } \\
\text { savings opportunities in the office. }\end{array}$ & (4) \\
\hline $\begin{array}{l}\text { Environmental } \\
\text { and social } \\
\text { sustainability }\end{array}$ & $S u=f(\mathrm{P} o+L u)$ & $\begin{array}{l}P o \text { and } L u \text { are pollution and land used, } \\
\text { respectively. Here, } P o \text { refers to pollution } \\
\text { from fossil fuels, such as; oil, coal, and gas, } \\
\text { while } L u \text { is land use to produce renewable } \\
\text { energy such as; solar, biomass, geothermal, } \\
\text { and wind. }\end{array}$ & (5) \\
\hline $\begin{array}{l}\text { Regulation } \\
\text { and } \\
\text { governance }\end{array}$ & $G o=f(I n+I f)$ & $\begin{array}{l}\text { In and If are interconnectivity and } \\
\text { information, respectively. In is an } \\
\text { interconnection between source to source of } \\
\text { energy generator or between user to user } \\
\text { energy. Whereas If is how to convey } \\
\text { consumption information and generation to } \\
\text { stakeholders. }\end{array}$ & (6) \\
\hline
\end{tabular}


Now, focus is how to integrate the local energy security system (LESS) into national energy security system (NESS) through the ICT of a smart city. Figure 3 shows the block diagram of integrating LESS and NESS to the smart city. At present, the local government in Indonesia is actively realizing a smart city vision. Then, ICT and smart grids are the foundation for making it happen soon. That is, the speed of local government is in pursuit of vision as a smart city, depending on how quickly it build ICT and smart grids. The most important assessment factor here lies in the Go dimension, with the In (interconnectivity) and If (information). When the Go has been realized, the other four dimensions will be easily obtained.

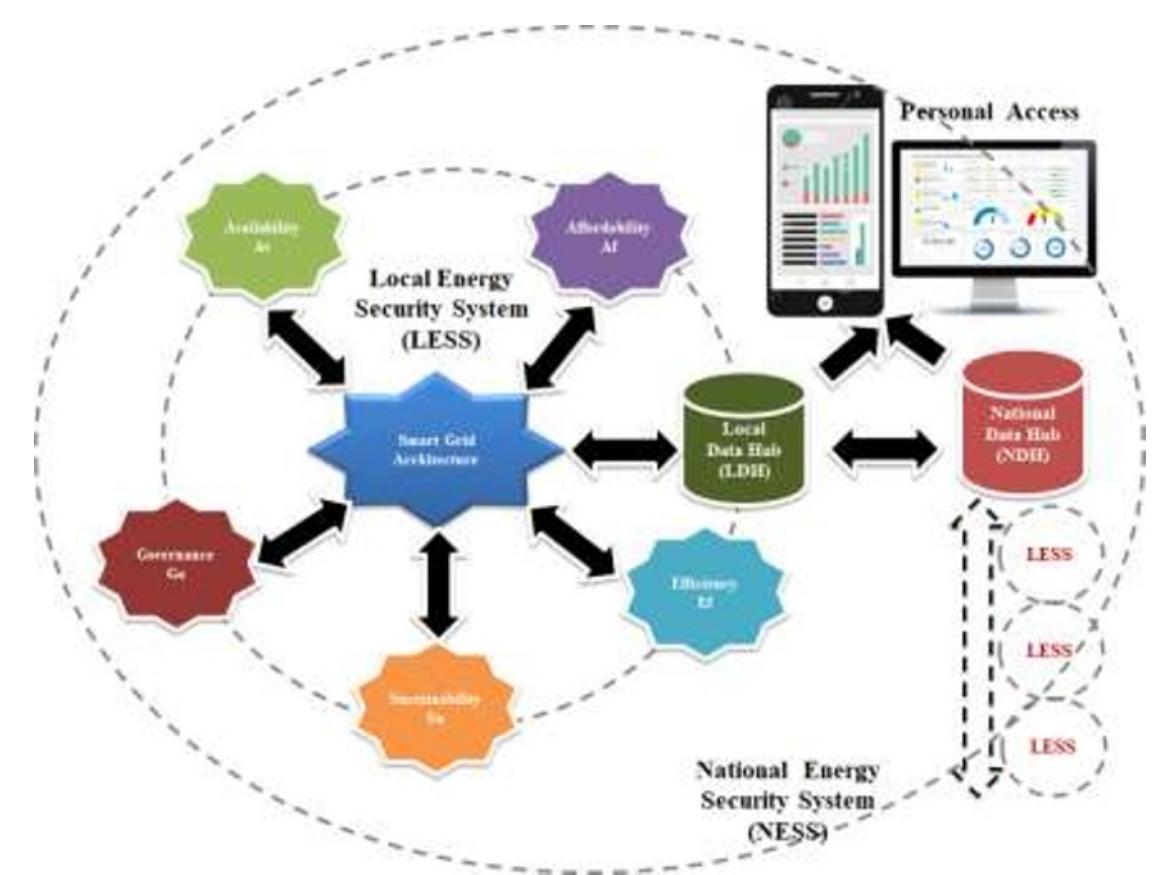

Fig. 3. Integrating local energy security system (LESS) into national energy security system (NESS)

Based on the concept of energy security integrated into the smart grid technology as described above, there are three points to be discussed. First, related to data. Not all data can be available online and in real-time, for example, affordability, etc. How to provide and access this data should be anticipated from the very beginning to design each LESS into smart grids. Fast, precise and accurate information about ES is very important for leaders in the regions in making important decisions related to energy issues. Second, related to energy security infrastructure by the local government. As the party that has the most interest in achieving energy security locally, the local government is challenged on how to prepare energy security infrastructure based on current conditions, regarding Figure 2 [12]. Third, related to the utilization of the local energy security system. In this case, the central government and regional governments have the same interest and position in utilizing LESS. Without strong LESS support, NESS is nothing. To make LESS strong, the central government must utilize the energy security items as the key energy performance indicators (KEPI) [7]. Here, the ES must be indexed [14].

In practice, the items in LESS can be used by KEPI, as a reference in providing economic incentives, development assistance, etc. Thus, LESS and NESS can work systematically to strengthen each other. The contribution of this research is to provide an 
overview of how the concept of energy security system development is closely related to the implementation of the smart grid, with a focus on the further development of renewable energy and energy efficiency. For renewable energy, the focus should be given on solar energy such as photovoltaic panels, thermal collectors, or hybrid photovoltaic and thermal collectors $[15,16]$, while energy efficiency is more focused on the building sector [17]. For future research directions, this energy security concept must be further developed by the needs and technological advances. The focus should be given to the technical item in LESS as well as the integration between LESS and smart grid technology.

\section{Conclusion}

The concept of developing an ICT-based energy security tracking system in Indonesia with an extension of the smart city design has been discussed. The concept of developing an ICT-based energy security tracking system in Indonesia with an extension of the smart city design has been discussed. The items related to the energy security system can be broken down into five important dimensions; such as availability, affordability, efficiency, sustainability, and government. The concept of integration of LESS into NESS involves a local data hub (LDH) and a national data hub $(\mathrm{NDH})$. This concept can be accessed by the central government in evaluating local government performance on energy, which can be linked to the intensive programs and development assistance.

\section{References}

1. International Energy Agency (IEA). Energy security 2018. [Online] from http://www.iea.org/topics/energysecurity/subtopics/whatisenergysecurity/ (2018). (Accessed on April 22, 2018).

2. J. Jin, J. Gubbi, S. Marusic, M. Palaniswami, IEEE Internet Things J., 1,2:112121(2014). https://ieeexplore.ieee.org/document/6702523

3. C. Clastres, Energy Policy, 39:5399-5408(2011). https://www.sciencedirect.com/science/article/pii/S030142151100396X

4. C. Feder, Technol. Forecast Soc. Change, 126:186-193(2018). https://ideas.repec.org/a/eee/tefoso/v126y2018icp186-193.html

5. M.E. El-Hawary. Electr. Power Components Syst., 42:239-250(2014). https://www.tandfonline.com/doi/abs/10.1080/15325008.2013.868558

6. S. Praharaj, H. Han, City, Cult. Soc., 18:100289(2019). https://www.sciencedirect.com/science/article/pii/S1877916618302935

7. E. Yandri, R. Ariati, R.F. Ibrahim, J. Ketahanan Nas., 24,2:239-260(2018). [in Bahasa Indonesia]. https://dev.jurnal.ugm.ac.id/jkn/article/view/30999

8. S. Suakanto, S.H. Supangkat, Suhardi, R. Saragih, Smart city dashboard for integrating various data of sensor networks, International Conference on ICT for Smart Society, (Jakarta, Indonesia, 2013), p. 1-5. https://ieeexplore.ieee.org/document/6588063

9. B.K. Sovacool, I. Mukherjee, Energy, 36,8:5343-5355(2011). https://www.sciencedirect.com/science/article/pii/S0360544211004294

10. E. Yandri, R. Ariati, R.F. Ibrahim, Improving energy security model through detailing renewable and energy efficiency indicators: A concept for manufacture industry. SIGER 2017, (Universitas Lampung, Indonesia (2017), p. 9. [Research paper]. http://repository.unsada.ac.id/1038/ 
11. Deloitte. Smart Cities: The importance of a smart ICT infrastructure for smart cities. [Online] from

https://www.stokab.se/Documents/Nyheter\%20bilagor/SmartCityInfraEn.pdf (2017). (Accessed on April 22, 2018).

12. V.C. Gungor, D. Sahin, T. Kocak, S. Ergut, C. Buccella, C. Cecati, et al. IEEE transactions on Industrial informatics, 7,4:529-539(2011).

https://ieeexplore.ieee.org/abstract/document/6011696/

13. BPPT. Indonesia Energy Outlook 2016. Jakarta, Indonesia: BPPT(2016)

[In Bahasa Indonesia]. https://www.bppt.go.id/outlook-energi/bppt-outlook-energiindonesia-2016

14. B.K. Sovacool, Ecol. Econ., 88:148-158(2013).

https://www.sciencedirect.com/science/article/pii/S0921800913000396

15. E. Yandri, Renew. Energy, 111:344-352(2017).

https://www.sciencedirect.com/science/article/pii/S0960148117302860

16. E. Yandri, Sol. Energy Mater. Sol. Cells, 201:10066(2019). https://www.sciencedirect.com/science/article/pii/S0927024819303952

17. Yandri, E., Ariati, R., Uyun, A. S., Setyobudi, R. H., Anne, O., Susanto, H., \& Vincevica-Gaile, Z. Implementation of walk-through audits for designing energy management system: A first step towards an efficient campus. ICEA-2019, (Surabaya, Indonesia, 2019), IOP Conference Series: Earth and Environmental Science 490,1:012005(2020).

https://iopscience.iop.org/article/10.1088/1755-1315/490/1/012005/meta 